\title{
Glycosylated VCAM-I isoforms revealed in 2D western blots of HUVECs treated with tumoral soluble factors of breast cancer cells
}

\author{
Delina Montes-Sánchez ${ }^{1,2,3}$, Jose Luis Ventura1,2, Irma Mitre ${ }^{1,2}$, \\ Susana Frías ${ }^{1,2}$, Layla Michán ${ }^{1,2}$, Aurora Espejel-Nuñez ${ }^{4}$, Felipe Vadillo- \\ Ortega $^{5}$ and Alejandro Zentella*1,2
}

\begin{abstract}
Address: ${ }^{1}$ Departamento de Medicina Genómica y Toxicología Ambiental, Instituto de Investigaciones Biomédicas, UNAM. Ciudad Universitaria, Circuito Interior apartado postal 70228, CP04510, México DF, ²Departamento de Bioquímica, Instituto Nacional de Ciencias Médicas y Nutrición "Salvador Zubirán", SSA Vasco de Quiroga no 15 Colonia Sección XVI, Delegación Tlalpan. CP.4080, México DF, ${ }^{3}$ Dirección de Investigación Básica, Instituto Nacional de Cancerología, SSA Av San Fernando no 22 Col. Sección XVI, Tlalpan, CP 14080, México DF, ${ }^{4}$ Dirección de Investigación, Instituto Nacional de Perinatología, SSA Montes Urales 800 Torre de Investigación $5^{\circ}$ piso, Colonia Lomas Virreyes, Delegación Miguel Hidalgo, CP11000, México DF and ${ }^{5}$ Edificio de Investigación, Facultad de Medicina, UNAM. Ciudad Universitaria, Circuito Interior apartado postal 70228, CP04510, México DF
\end{abstract}

Email: Delina Montes-Sánchez - dely.ms@gmail.com; Jose Luis Ventura - venturag@biomedicas.unam.mx; Irma Mitre - irmamitre@yahoo.com; Susana Frías - mssfrias@gmail.com; Layla Michán - laylamichan@yahoo.com; Aurora Espejel-Nuñez - aurora_espnu@yahoo.com.mx;

Felipe Vadillo-Ortega - felipe.vadillo@gmail.com; Alejandro Zentella* - azentell@biomedicas.unam.mx

* Corresponding author

Published: 22 November 2009

BMC Chemical Biology 2009, 9:7 doi:10.1 186/1472-6769-9-7

This article is available from: http://www.biomedcentral.com/1472-6769/9/7

(C) 2009 Montes-Sánchez et al; licensee BioMed Central Ltd.

This is an Open Access article distributed under the terms of the Creative Commons Attribution License (http://creativecommons.org/licenses/by/2.0), which permits unrestricted use, distribution, and reproduction in any medium, provided the original work is properly cited.

\begin{abstract}
Background: Several common aspects of endothelial phenotype, such as the expression of cell adhesion molecules, are shared between metastasis and inflammation. Here, we analyzed VCAMI variants as biological markers of these two types of endothelial cell activation. With the combination of 2-DE and western blot techniques and the aid of tunicamycin, we analyzed $\mathrm{N}$ glycosylation variants of VCAM-I in primary human endothelial cells stimulated with either TNF or tumoral soluble factors (TSF's) derived from the human breast cancer cell line ZR75.30.

Results: Treatments induced a pro-adhesive endothelial phenotype. 2D western blots analysis of cells subjected to both treatments revealed the expression of the two known VCAM-I isoforms and of previously unknown isoforms. In particular TSFZR75.30 induced an isoform with a relative molecular mass $(\mathrm{Mr})$ and isoelectric point $(\mathrm{pl})$ of $75-77 \mathrm{kDa}$ and 5.0, respectively.

Conclusion: The unknown isoforms of VCAM-I that were found to be overexpressed after treatment with TSF's compared with TNF, could serve as biomarkers to discriminate between inflammation and metastasis. 2D western blots revealed three new VCAM-I isoforms expressed in primary human endothelial cells in response to TSF stimulation. Each of these isoforms varies in $\mathrm{Mr}$ and $\mathrm{pl}$ and could be the result of differential glycosylation states.
\end{abstract}




\section{Background}

Endothelial cells line the inside of all blood vessels forming an interface between circulating blood and the underlying tissues. As such, endothelial cells comprise, a critical metabolic organ involved in the generation and regulation of multiple physiological and pathological processes such as coagulation, hemostasis of local vascular pressure, inflammation, atherosclerosis, angiogenesis, and metastasis [1]. In the context of the current model of tumoral dissemination, glycoproteins including cell adhesion molecules are expressed on the apical endothelial membrane, interacting with counter-receptors on circulating cancer cells, facilitating the spread of the disease $[2,3]$.

Glycoproteins are prominent constituents of biological membranes, and are involved in various biological functions, including immunological protection, enzymatic catalysis, hormonal control, ion transport, structural support, molecular recognition, and cell adhesion. Structurally, glycoproteins are comprised of a peptide backbone, with carbohydrate chains covalently attached to asparagine ( $\mathrm{N}$-glycan) or serine/threonine (O-glycan) residues $[4,5]$. The immunoglobulin super family of cell adhesion molecules (IgCAMs) constitutes a large group of cell surface glycoproteins that are specialized for cell-cell adhesion $[6,7]$. Recently, these molecules have been reported to play an important role in pathological processes, including tumor invasion and metastasis $[8,9]$. In particular, vascular adhesion molecule-1 (VCAM-1) is a cell surface glycoprotein expressed on the apical membrane of endothelial cells activated by cytokines $[10,11]$. Two isoforms of VCAM-1 have been reported, a full length protein (a) and a smaller version (b) lacking exon 5. Their expression occurs in response to inflammatory mediators and is dependent on the translocation of the transcription factor NF- $\mathrm{BB}$ into the nucleus [12]. VCAM-1 interacts with its integrin counter receptor very late antigen-4 (VLA-4), to mediate the recruitment of leukocytes [13-15]. The adhesion of tumor cells to the apical endothelial membrane resembles their interaction with leukocytes when endothelial cells have been activated with tumor necrosis factor (TNF). TNF is a pro-inflammatory cytokine, principally derived from mononuclear phagocytes, that induces transient phenotypic changes in the endothelial cells, transforming their apical membrane from a quiescent non-adhesive to an activated pro-adhesive surface amenable for cell-cell interactions [16-18].

We have previously reported that the tumoral soluble factors (TSF's) with a very low to none TNF content can induce a strong pro-adhesive phenotype similar to the one induced by TNF [19-21]. Here we analyzed changes in the content of VCAM-1 in endothelial cells under experimental treatments with TNF or TFS's that led to an increase in tumor cell adhesion. We combined enhanced chemiluminescent sensitive (ECL) detection with the high resolving power of two-dimensional polyacrylamide gel electrophoresis (2-DE), using these techniques and the aid of tunicamycin were able to identify undescribed isoforms of VCAM-1.

\section{Results \\ Tumoral soluble factors (TSF's) secreted by human breast cancer cell lines induced adhesion of U937 myelomae cells to HUVECs}

Using an in vitro cell adhesion assay, we found that tumor soluble factors (TSF's) induced an activated phenotype of HUVECs (Figure 1). The cells were stimulated for $3 \mathrm{~h}$ with either TNF $(10 \mathrm{ng} / \mathrm{ml})$ or TSF's derived from breast cancer cells lines: MCF-7 and ZR75.30 (1 $\mu \mathrm{g} / \mathrm{ml})$, (labeled TSFMCF-7 and TSFZR75.30, respectively), diluted in M199 medium. Then, the medium containing TNF or TSF's was removed, and the HUVECs were coincubated for 3 more h with previously radio-labeled U937 cells as was described in methods. Compared to untreated control cells, HUVECs treated with TNF presented a 2.6 fold increase in cell adhesion, while those treated with TSFZR75.30 had a 1.5 induction. The soluble factors secreted by the other breast cancer cell line (TSFMCF-7) did not show any adhesive effects. These results indicate that TSFZR75.30 induced a pro-adhesive phenotype similar to that induced by TNF.

\section{Biochemical contents of TSFZR75.30}

We used a Bio-Plex system ${ }^{\text {TM }}$ by BIO-RAD, CA. $[16,22]$ to evaluate the content of cytokines, chemokines, and growth factors in TSFZR75.30. The results are summarized in Table 1. TSFZR75.30 contained four cytokines (IL-6, IL8 , G-CSF, MCP-1) that were present at levels above the maximum measured limit. Nine cytokines (IL-2, IL-4, IL10, IL-5, IL-7, IL-9, IP-10, MIP-1 $\alpha$, RANTES) were below the minimum measurable limit, and thirteen were present at low levels within the detectable range, TNF was present in this group. In comparison with the amount used (10 $\mathrm{ng} / \mathrm{ml})$, TNF was 50 times less abundant $(0.22 \mathrm{ng} / \mathrm{ml})$ in the mixture of TSFZR75.30. Taken together, these results suggest that TSFZR75.30 contain cytokines, chemokines, and growth factors that are able to induce a proadhesive phenotype in endothelial cells.

TSFZR75.30 induced the expression of VCAM-I isoforms in HUVECs that disappeared when the cells were pre-treated with tunicamycin

VCAM-1 is a classic cell adhesion molecule, with a $\mathrm{Mr}$ $\sim 80-110$, that is expressed during the inflammatory response and has also been associated with tumoral dissemination [23-25]. VCAM-1 is a surface molecule reported to have two isoforms: i) the complete form (a), 


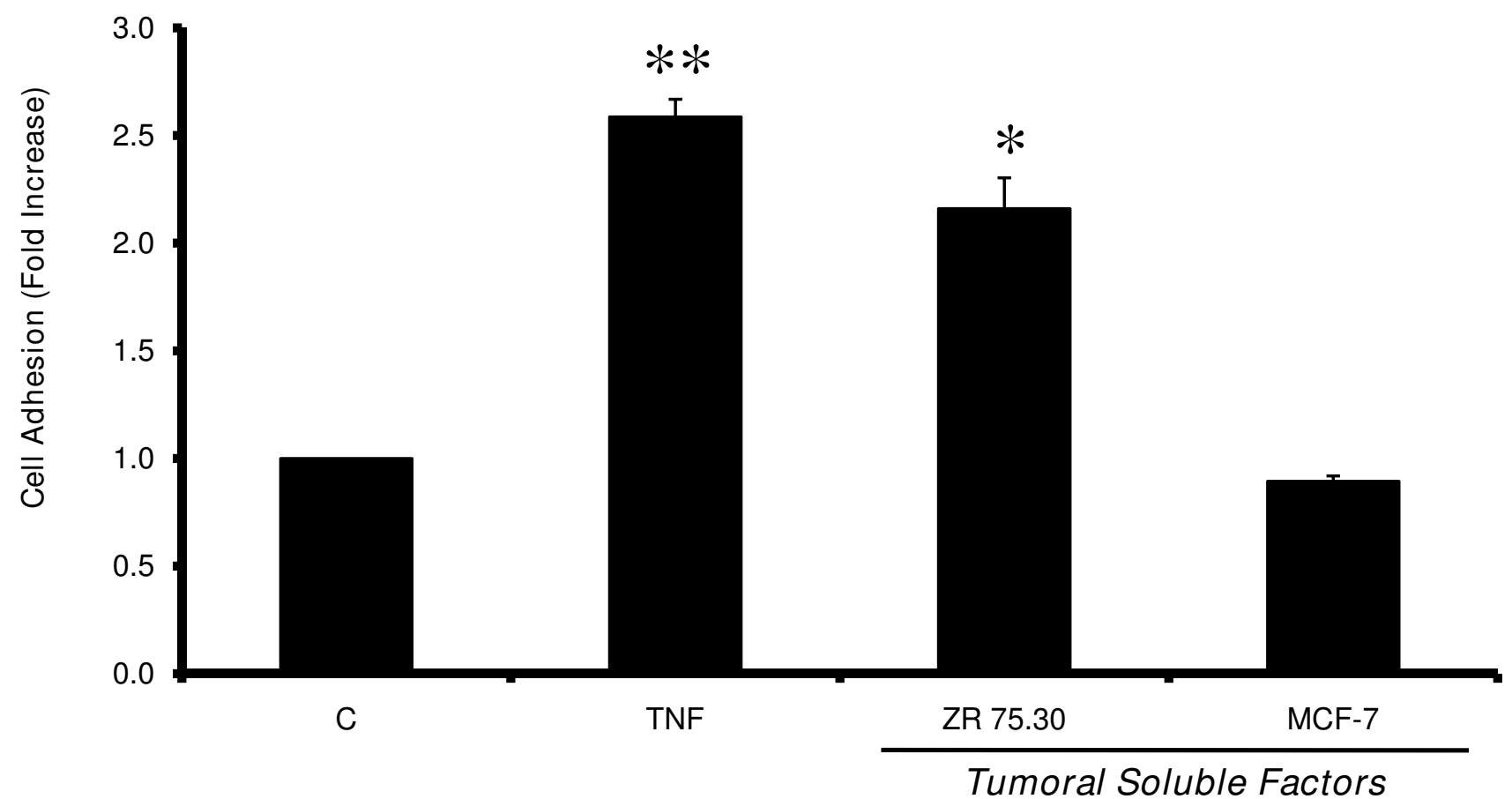

Figure I

Tumoral soluble factors derived from breast cancer cell line ZR75.30 increase adhesion. The cell adhesion assay shows the endothelial activation, which is proportional to the adhesion of human myeloma U937 cells to HUVECs. Each bar represents the average of three independent experiments performed in triplicates. Statistical significance when compared to the control group is defined as: $p<0.05\left(^{*}\right)$ and $p<0.01(* *)$. The error bars indicate \pm standard error of the mean.

composed of 739 amino acid residues encoded by nine exons and containing six $\mathrm{N}$-glycosylation sites that are indispensable for protein function during molecular recognition with integrins, and ii) the small form (b), which is composed of 647 residues and results from an alternative splicing event that removes exon 5, eliminating the second N-glycosylation site (Figure 2A). The changes in the cellular content of VCAM-1 were evaluated by western blots analysis from total extracts of HUVECs treated with either TNF or TSFZR75.30 for $6 \mathrm{~h}$ (Figure 2B). The content of VCAM-1 in cells treated with TNF $(10 \mathrm{ng} / \mathrm{ml})$ and TSFZR75.30 $(1 \mu \mathrm{g} / \mathrm{ml})$ was increased. The two reported isoforms appeared as a tight doublet (VCAM-1a, Mr 90$95 \mathrm{kDa}$ and VCAM-1b 80-83 kDa) (lanes 3 and 5). Compared to the control, VCAM-1a isoform increased 41 and 60 fold, while isoform VCAM1b increased 10 and 15 fold. However, when we pre-treated cells for $3 \mathrm{~h}$ with tunicamycin $(1 \mu \mathrm{g} / \mathrm{ml})$, an inhibitor of $\mathrm{N}$-glycosylation, only the band corresponding to isoform "a" was visible in TNFtreated HUVECs (lane 4). In the case of treatment with the TSFZR75.30, a new isoform was revealed, with a $\mathrm{Mr} \sim 77$ $\mathrm{kDa}$, in addition to isoform "a" (lane 6). In both cases isoform "b" was absent. Expression of isoform "a" and the new isoform, labeled as "x", was increased 17 and 15 fold respectively, to the control. It is clear that tunicamycin had a differential effect on the glycosylation state and the content level of VCAM-1 isoforms, leading to the disappearance of isoform " $b$ " and the emergence of a undescribed VCAM-1 isoform in cells treated with TSFZR75.30, labeled here as isoform " $x$ ". When we performed a cell adhesion assay similar to the one describe in Figure 1, on cell that had been pretreated with tunicamycin $(1 \mu \mathrm{g} / \mathrm{ml})$ for $3 \mathrm{~h}$. The fold increase in cell adhesion induced by TSFZR75.30 fell from $3.1 \pm 0.5$ to $1.7 \pm 0.3$ in control HUVECs compared to cells pretreated with tunicamycin. These results indicate that $50 \%$ of the observed cell adhesion is dependent from N-glycosylations.

\section{2-DE analysis of total extracts of HUVECs treated with TNF or TSFZR75.30}

In an attempt to further characterize the different VCAM1 isoforms visualized in Figure 2B, we prepared 2-DE gels that were stained with a fluorescent dye (Deep purple ${ }^{\mathrm{TM}}$ ) and analyzed, focusing on the regions expected to contain these isoforms. Two dimensional electrophoresis of total extracts from HUVECs treated with TNF presented 191 spots, $24 \%$ more than control cells (154 spots) or those treated with TSFZR75.30 (150 spots) (Figure 3, upper 
Table I: Elements contained (pg/ml) in TSFZR75.30 examined by Bio-Plex array.

\begin{tabular}{|c|c|c|c|}
\hline & TSFZR75.30 & Maximum detected & Minimum detected \\
\hline IL-2 & $<1.3$ & 21517 & 1.3 \\
\hline IL-4 & $<0.2$ & 3854 & 0.2 \\
\hline IL-6 & $>33053$ & 33053 & 2.0 \\
\hline IL-8 & $>24800$ & 24800 & 1.5 \\
\hline IL- 10 & $<1.9$ & 30108 & 1.9 \\
\hline GM-CSF & 354 & 10791 & 0.6 \\
\hline $\mathrm{IFN} \gamma$ & 112.5 & 40543 & 2.5 \\
\hline TNF & 22.5 & 70463 & 4.3 \\
\hline IL-I $\beta$ & 49.9 & 37082 & 2.3 \\
\hline IL-5 & $<2.4$ & 39452 & 2.4 \\
\hline IL-7 & $<2.7$ & 44339 & 2.7 \\
\hline IL-I2 & 12.5 & 41843 & 2.5 \\
\hline IL-I3 & 29.5 & 33114 & 2.0 \\
\hline IL-I7 & 13 & 26740 & 1.6 \\
\hline G-CSF & $>28728$ & 28728 & 1.7 \\
\hline MCP-I & $>27978$ & 27978 & 1.7 \\
\hline MIP-I $\beta$ & 15.5 & 37041 & 2.2 \\
\hline IL-Ir $\alpha$ & 130.5 & 42658 & 2.6 \\
\hline IL-9 & $<1.6$ & 27064 & 1.6 \\
\hline IL-I5 & 13 & 26368 & 1.6 \\
\hline Eotaxin & 8.5 & 24294 & 1.5 \\
\hline FGF-basic & 9 & 18355 & 1.1 \\
\hline IP- 10 & $<4.3$ & 69784 & 4.3 \\
\hline MIP-I $\alpha$ & $<1.1$ & 18493 & I.I \\
\hline PDGF-BB & 14.5 & 32062 & 1.9 \\
\hline RANTES & $<1.5$ & 24678 & 1.5 \\
\hline VEGF & I I590.5 & 39592 & 2.4 \\
\hline
\end{tabular}

panels). The dotted rectangles correspond to the position ( $\mathrm{Mr}$ and $\mathrm{pI}$ ) predicted for the VCAM-1 isoforms. An amplified view of this region appears in the lower panels; 16 spots were detected with variations in intensity between treatments. However, none of the spots replicated the increase in the amounts of VCAM-1 isoforms observed in the westerns blots from Figure 2B. It is possible that the amount of protein on the gels was not enough to visualize the VCAM-1 isoforms.

\section{Proteic isoforms of VCAM-I can be observed in 2D westerns of HUVECs treated with TNF or TSFZR75.30}

Considering that the resolution of the 2-DE gels was adequate and that the western blots analysis of VCAM-1 expression yielded intense signals, we combined these two approaches and performed 2D western blots that revealed an unexpected variety of VCAM-1 isoforms (Figure 4). We identified the only barely visible spot in the untreated control cells that displayed $\mathrm{Mr} / \mathrm{pI}$ values close to those reported for the full length as the VCAM-1 isoform "a" (Mr 90-95 kDa/pI 4.8) (Figure 4C, left panels). The expression of this isoform was significantly increased when cells were treated with TNF or with TSFZR75.30. With TNF (T) two isoforms, labeled as "b" (Mr $\sim 80 \mathrm{kDa} /$ $\mathrm{pI} 4.6)$ and "c" (Mr $\sim 83 \mathrm{kDa} / \mathrm{pI} 5.1-5.2)$, appeared below isoform " $\mathrm{a}$ ". With TSFZR75.30 (ZR), three spots were vis- ible: two corresponded with spots "b" and "c" and a third additional isoform labeled as "d" ( $\mathrm{Mr} \sim 77 \mathrm{kDa} / \mathrm{pI} 5.0)$ also became apparent.

Following the same strategy used in Figure 2 to reveal isoforms with different $\mathrm{N}$-glycosylation states, we resolved using 2D westerns blots, total extracts from HUVECs pretreated with tunicamycin. Figure $4 \mathrm{C}$, right panels indicate that the faint spot we previously identified as isoform "a" in the untreated control cells disappeared after tunicamycin treatment. HUVECs treated with TNF (Figure 4T, right panels), showed a spot with the same Mr as isoform "a", but with a shift in isoelectric point from 4.8 to 5.3-5.4, along with a fifth isoform (labelled as "e") that appeared as a faint spot $(\mathrm{Mr} \sim 77 \mathrm{kDa} / \mathrm{pI} 6.0)$. These isoforms (a and e) were also visible in cells treated with TSFZR75.30 (Figure 4ZR right panels). The isoform " $e$ " was the most basic spot detected and had the same apparent $\mathrm{Mr}$ as isoform "d" (Table 2). Interestingly, VCAM-1 isoform " $\mathrm{x}$ " seen in Figure 2B displayed a similar $\mathrm{Mr}(75 \mathrm{kDa})$ as isoforms "d" and "e" (77 kDa) shown in Figure 4. Thus, in addition to the isoforms " $a$ " and " $b$ " previously reported in the literature, resulting from alternative splicing events, our 2D western blots analysis revealed three new isoforms defined by differential states of $\mathrm{N}$-glycosylation. 

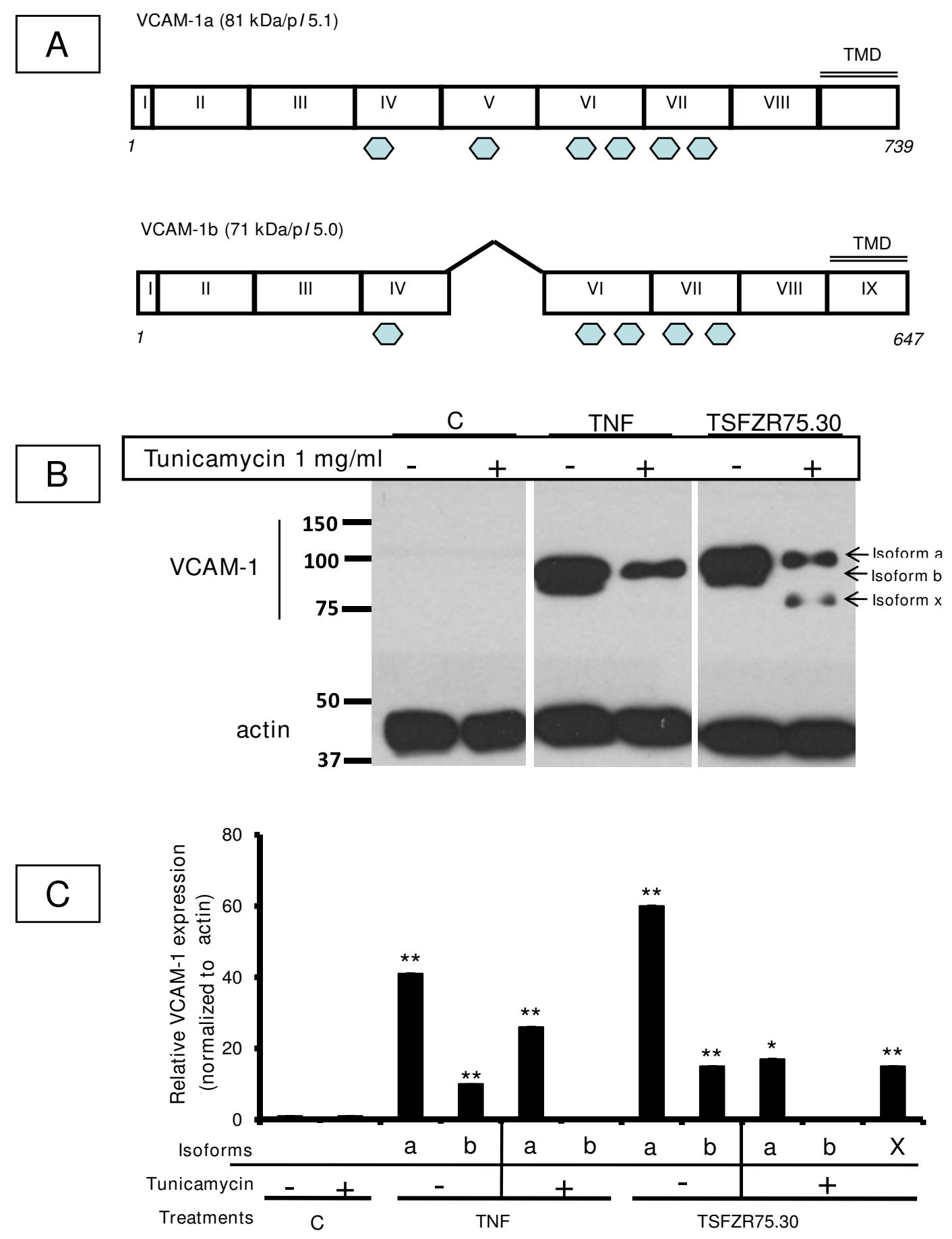

Figure 2

Expression of VCAM-I cell content is increased when HUVECs are treated with TSFZR75.30 and decreased when cells are pre-treated with tunicamycin. A) Exon maps of VCAM- Ia: 739 amino acid, 9 exons and $6 \mathrm{~N}$-glycosylation sites and, VCAM-I b: 647 residues, lacking exon 5 and the 2 nd $\mathrm{N}$-glycosylation site (hexagons). B) Western blot to detect VCAM-I in twenty micrograms of total extracts from HUVECs treated for $3 \mathrm{hr}$ with TNF or TSFZR75.30 (lanes 3,5) or pretreated with tunicamycin $3 \mathrm{~h}$ before TNF or TSF's (lanes 4,6). C) Histogram of the mean of three individual experiments and the normalized densitometric values reflecting expression of the VCAM-I isoforms: $a, b$ and $x$ with respect to actin signal. $p<$ 0.001 (*) compared control. The error bars indicate \pm standard error of the mean. 


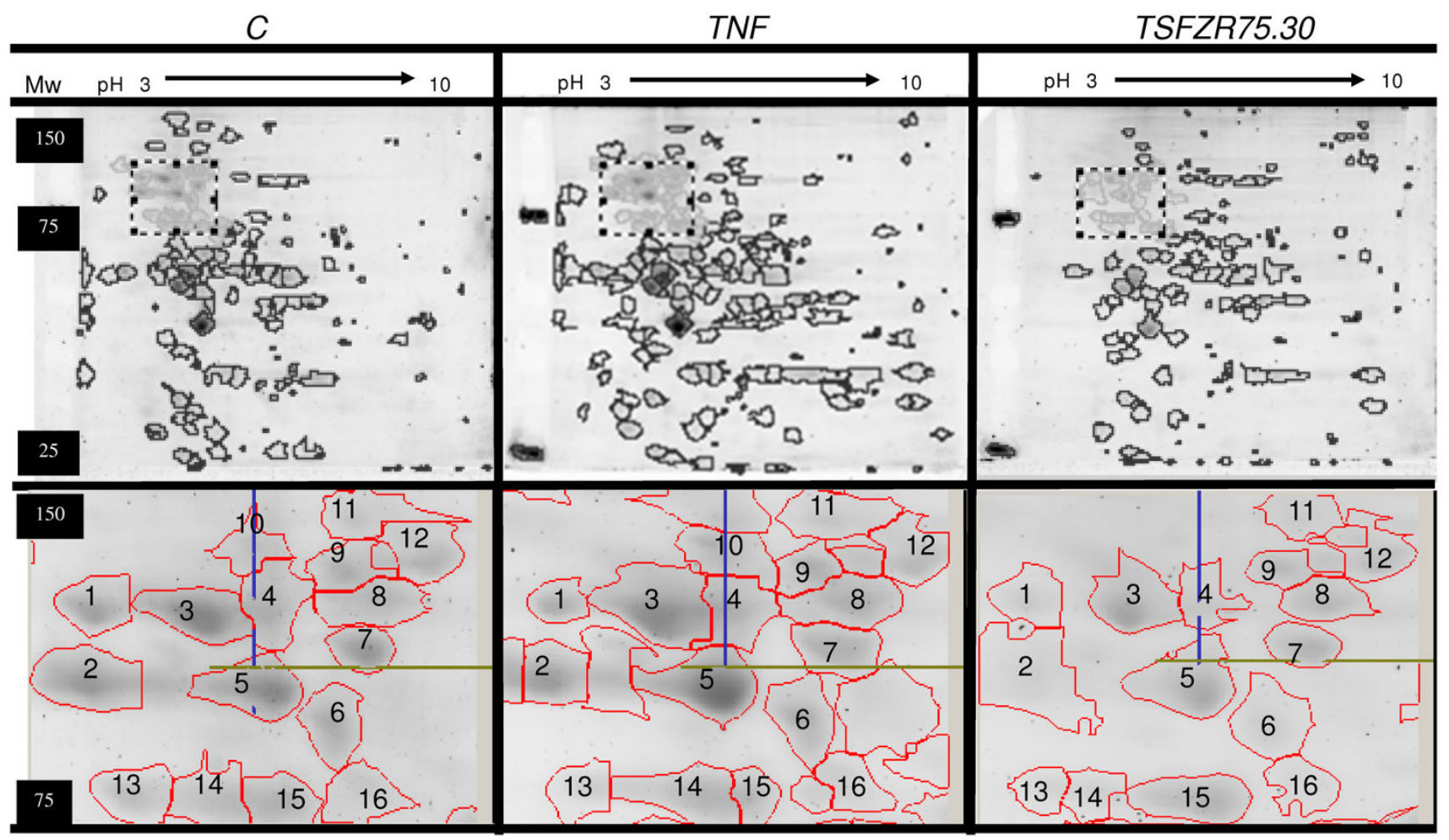

Figure 3

Informatic analyses with the program Image Master 2D Platinum ${ }^{\mathrm{TM}} .50 \mu \mathrm{g}$ of total extracts were loaded and stained with the Deep-Purple fluorochrome ${ }^{\mathrm{TM}}$. The $\mathrm{I}^{\text {st }}$ dimension was resolved in a linear $\mathrm{pH}$-range from $3-10$ and in $10 \%$ acrylamide for the $2^{\text {nd }}$ dimension. Control (C): left panels; TNF: central panels; TSFZR75.30: right panels. Lower panels represent an amplified view of the dotted rectangle in the upper panels. Patterns are the representative images of three individual experiments each performed in duplicate.

\section{Translocation of NF- $\kappa B$ to the nucleus in HUVECs treated with TSFZR75.30}

Since VCAM-1 expression in response to TNF has been reported to be dependent on NF- $\kappa \mathrm{B}$ activation, we tested by EMSA whether TSFZR75.30 could elicit a similar translocation of active NF- $\kappa \mathrm{B}$ to the nucleus in HUVECs treated with these tumoral factors. Several DNA/NF- $\mathrm{B}$ complexes were visible, but only complex III increased in cells treated with TNF or TSFZR75.30 (Figure 5). While TNF treatment led to a 4 -fold increase with respect to control cells, TSFZR75.30 led to only a 2-fold increase (lane 4), despite the fact that this same treatment induces a strong pro-adhesive phenotype (Figure 1). As a negative control, we treated HUVECs with TSFMCF-7 and, as was expected, TSFMCF-7 did not promote translocation of NF- $\kappa \mathrm{B}$. In fact, a slight decrease in the signal was observed (lane 3). Hence, TSFZR75.30 was able to activate and translocate $\mathrm{NF}-\kappa \mathrm{B}$ to the nucleus.

\section{Discussion}

The interactions of tumor cells with their neighboring endothelial cells present in their surrounding environ- ment has emerged as an increasingly relevant factor in tumor progression during angiogenesis, intravasation at the primary tumor site, and adhesion and extravasation at the site of metastasis [26-28]. The available information indicates that the soluble factors secreted by tumor cells can alter the phenotype of different cell types, modifying their activity and provoking tissue destruction, tumoral cell migration and dissemination [29]. We have previously reported that HUVECs treated with soluble factors secreted by tumoral cells (TSF's), can adhere U937 cells and that this response is linked to the activation of NF- $\kappa \mathrm{B}$ and the expression of cell adhesion molecules [19,30].

Since Jaffe established the methodology for the culture in 1973, HUVECs had been the principal model to the studies of physiological and pathological process involved endothelial cells. For instance, previous studies have investigated functional differences between HUVECs (human umbilical vein endothelial cells) and HDMECs (human dermal microvascular endothelial cells) with respect to, upregulation of adhesion molecules in response to cytokines, stimulation and expression of sur- 


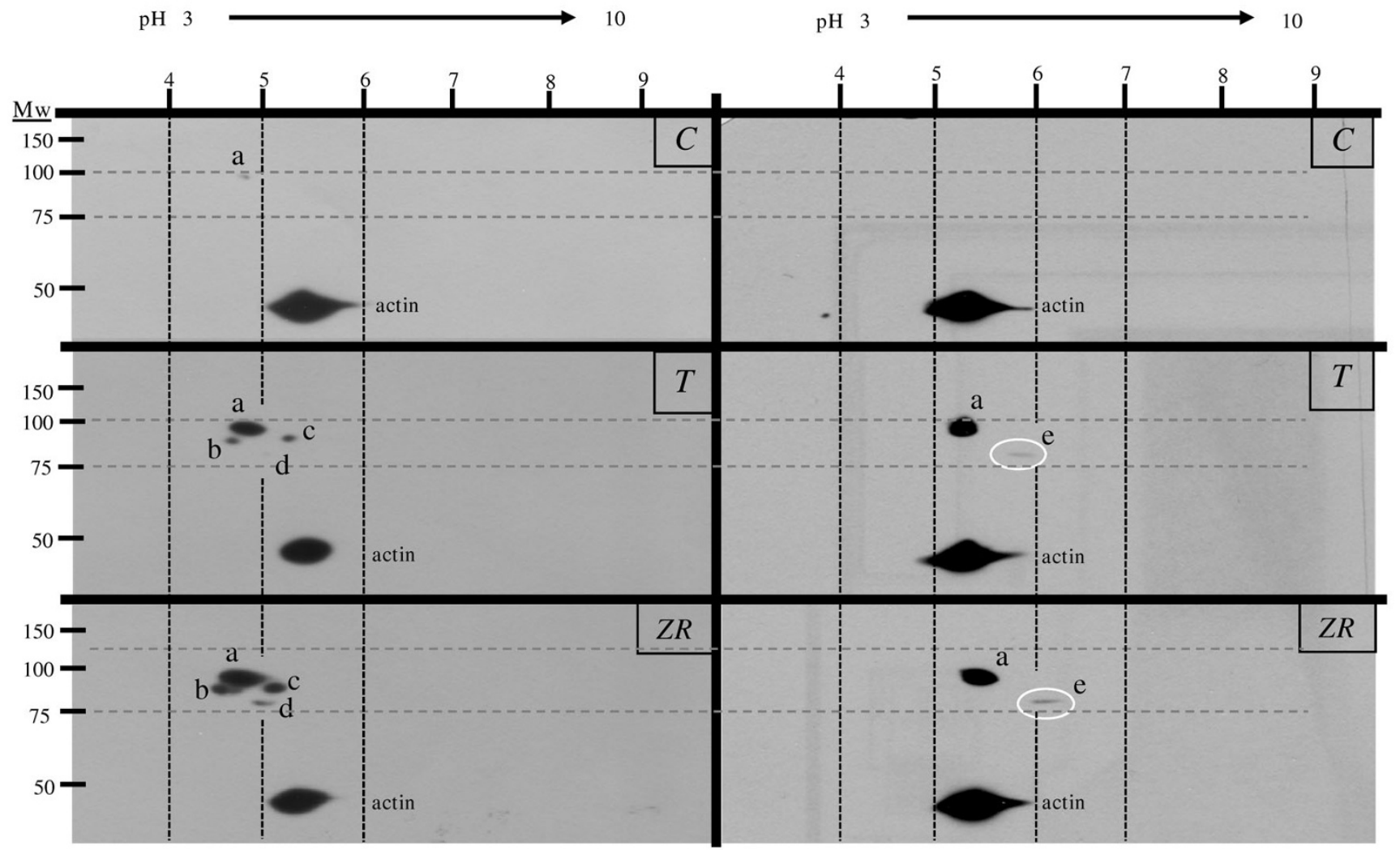

\section{Figure 4}

VCAM-I isoforms are observable in 2D western blots. $50 \mu \mathrm{g}$ of total protein from HUVECs was resolved in the |st dimension in a linear $\mathrm{pH}$-range from $3-10$ and in $10 \%$ acrylamide in the $2^{\text {nd }}$ dimension. Left panels: VCAM-I isoforms expression in control and treated HUVEC's. Right panels: VCAM-I isoforms expression observed in HUVECs with pre-treatment of tunicamycin. Control (C), TNF (T), TSFZR75.30 (ZR). The spot of actin was identified through a specific monoclonal antibody incubated at the same time as the VCAM-I antibody. Molecular weight markers are indicated to the left of the panels and $\mathrm{pH}$ gradient markers are indicated above. The dotted grids were added to facilitate the comparison between images. Patterns are the representative images of two individual experiments each performed in duplicate. Numbers in parenthesis after the spot of the VCAM-I isoform "a", reflect the relative amount with respect to samples without tunicamycin, each spot was normalized with the actin signal in the same gel, $\mathrm{p}<0.05(*) ; n=3$.

Table 2: Molecular weights and isoelectric points of VCAM-I isoforms.

\begin{tabular}{cccc}
\hline Isoform & Mr/pl NCBI & Mr/pl treatments & $\begin{array}{c}\text { Mr/pl } \\
\text { tunicamycin + treatments }\end{array}$ \\
\hline$a$ & $81 \mathrm{kDa} / 5.1$ & $90-95 \mathrm{kDa} / 4.8$ & $90-100 \mathrm{kDa} / 5.3-5.4$ \\
$b$ & $71 \mathrm{kDa} / 5.0$ & $80 \mathrm{kDa} / 4.6$ & not observable \\
c & not reported & $83 \mathrm{kDa} / 5.1-5.2$ & not observable \\
$d$ & not reported & $77 \mathrm{kDa} / 5.0$ & $77 \mathrm{kDa} / 5.9-6.1$ \\
e & not reported & not observable & $42 \mathrm{kDa} / 5.3$
\end{tabular}

\footnotetext{
Comparison between the values reported in the $\mathrm{NCBI}$ and the values observed by the treatments in the westerns of this study.
} 


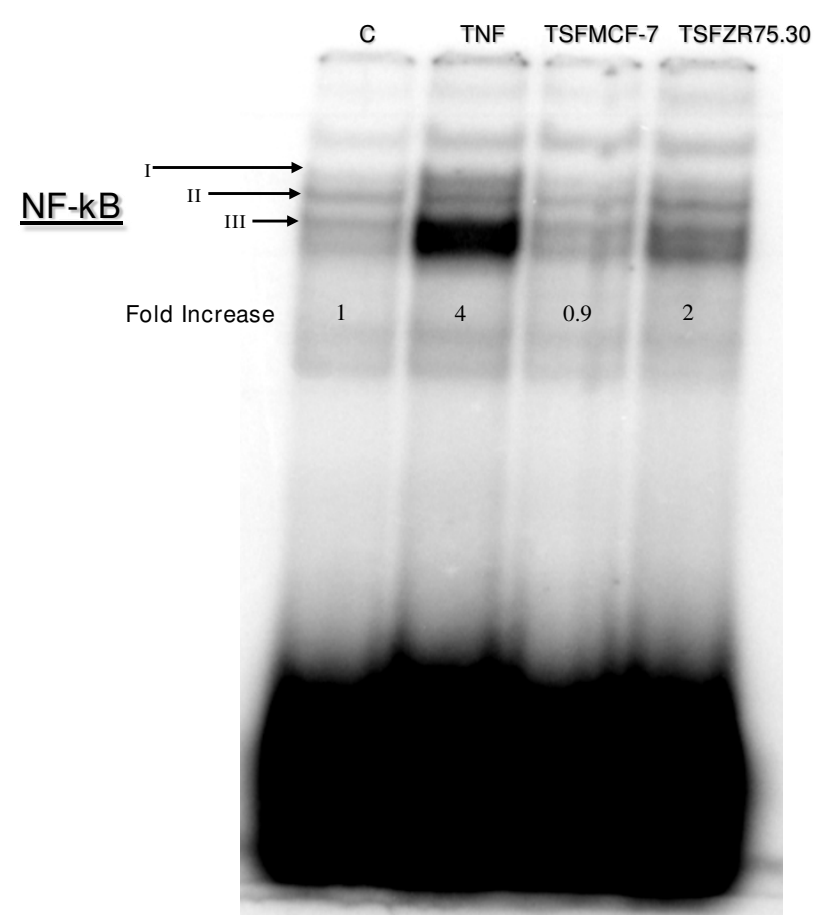

Figure 5

EMSA assay of the NF- $\kappa$ B translocation to the nucleus in HUVECs treated with TSFZR75.30.

Nuclear extracts from HUVECs untreated and treated with TNF, TSFMCF-7 or TSFZR75.30, were subjected to EMSA using a probe for NF- $\kappa$ B. Roman numbers indicate $N F \kappa B /$ DNA complexes. Numbers below the complexes correspond to relative intensity of complex III normalized against the control signal, are the mean of two individual experiments with independent cell cultures.

face antigens or mechanical properties of leukocytes rolling. However, at the moment does not exist clear functional differences. Histological studies of the expression of adhesion molecules, as such as VCAM-1 in primary vascular tumoral tissue, can serve to compare endothelial models with the behavior of cells in vivo [3133].

Our current working hypothesis is that the tumor cells can use adhesion molecules, such as VCAM-1, to interact with and adhere to the endothelial monolayers, essentially emulating leukocytes during the inflammatory reaction. In this work, we compared the increase in adhesive capacity of HUVEC's with the increased expression of different VCAM-1 isoforms.

A cell adhesion assay (Figure 1) was used to compare the pro-adhesive phenotype of HUVECs induced by TSF's. Since different tumor cell lines present variable adhesion to unstimulated endothelial cells, we used the promyelo- cytic human cell line U937 as a probe of the induction of pro-adhesive phenotype in response to the different TSF's. This assay showed that the factors derived from the cell line ZR75.30 (TSFZR75.30) were as effective as TNF in activating the endothelial phenotype, using the concentration of TSF's in which the percentage of adhesion $(1 \mu \mathrm{g} /$ $\mathrm{ml}-50 \%$ ), was the highest and did not have differences statistically significatives, with respect to another concentrations $(0.5 \mu \mathrm{g} / \mathrm{ml}-38 \%, 0.25 \mu \mathrm{g} / \mathrm{ml}-24 \%, 0.125 \mu \mathrm{g} / \mathrm{ml}-$ $19 \%, 0.0625 \mu \mathrm{g} / \mathrm{ml}-18 \%)$. TSF's by other three breast cancer cell lines were prepared and tested in the same cell adhesion assay (T47D, MDA MB 435 and MDA MB 231). Addition of $1 \mu \mathrm{g} / \mathrm{ml}$ of TSF's from either induced different fold increase of adhesion: $1.3 \pm 0,1.6 \pm 0.2,2.2 \pm 0.1$ respectively.

TNF is recognized as the most important physiological stimulus for the activation of signaling pathways that lead to the translocation of NF- $\mathrm{KB}$ into the nucleus, for several cell types [34-36]. In HUVECs, TNF and TSFZR75.30 both induced the translocation of NF- $\mathrm{BB}$ to the nucleus, although the TSF's only stimulated the system by about $50 \%$ in comparison with TNF (Figure 5). However, the amount of VCAM-1 expressed was slightly higher in TSFZR75.30 treated cells, suggesting that expression of this adhesion molecule could result from the recruitment of other transcription factors activated by the mixture of elements present in the TSF's. The analysis of the mixture of TSFZR75.30 revealed very low levels of TNF, along with an abundance of cytokines such as IL- 6 and IL-8 that could be responsible for NF- $\mathrm{KB}$ activation.

The expression of adhesion molecules, such as VCAM-1, in response to chemokines and cytokines is essential in the acute inflammatory response and represents a clear sign of an activated endothelial phenotype [35,37-39]. Unidimensional and bidimensional western blots analysis $[40,41]$ revealed that TSFZR75.30 was able to induce the expression of VCAM-1a ( $\mathrm{Mr} 81 \mathrm{kDa} / \mathrm{pI} 5.1)$ [NCBI access number NP_001069] and VCAM-1b (Mr $71 \mathrm{kDa} / \mathrm{pI}$ 5.0) [NCBI access number NP_542413] in HUVECs in a similar magnitude as TNF (Figure 2A).

In addition, the westerns showed four new isoforms: isoform $\mathrm{x}$ in uni-dimensional gels (Figure $2 \mathrm{~B}$ ) and isoforms $c, d$, and e in bi-dimensional gels (Figure 4). Isoforms c, d and e were present both, in cells treated with TNF as well as in those treated with TSFZR75.30, although isoform d was bearly visible in cells treated with TNF. We conclude that TSFZR75.30 promote a stronger expression of all isoforms compared to the induction mediated by TNF. In an attempt to determine if the isoforms contained N-glycosylations, we interfered with the formation of dolicholpyrophosphate $\mathrm{N}$-acetylglucosamine, the first step in the synthesis of $\mathrm{N}$-linked glycoproteins, by using tunicamy- 
cin. Under this condition, the protein portion of glycoproteins will be synthesized completely devoid of $\mathrm{N}$ glycosylations [42]. VCAM-1a has six N-glycosylation sites, whereas removal of exon 5 in VCAM-1b eliminates the second of these sites. Proteins lacking N-glycosylation have been reported to have decreased stability in the endoplasmic reticulum and hence, are more easily exported and degraded in the cytoplasm by the proteasome. This is a likely explanation for the decreased cellular content of isoform "a" ( $40 \%$ and $70 \%$ decrease with TNF or TSFZR75.30 respectively) and the disappearance of isoform " $b$ " in the presence of tunicamycin (Figure 2B and Figure 4).

The isoform " $\mathrm{x}$ " (Mr 75-77 kDa) (Figure 2B), became visible only in the presence of tunicamycin. Considering that one $\mathrm{N}$-glycosylation modification corresponds to an added weight of $3 \mathrm{kDa}$ and that VCAM1a (90-95 kDa) has six N-glycosylation sites, tunicamycin treatment could lead to isoforms that are up to $18 \mathrm{kDa}$ smaller. Hence, isoform " $\mathrm{x}$ " could correspond to the full length core protein (9 exons) lacking all $\mathrm{N}$-glycosylation modifications. At this point we cannot discard that the TSFZR75.30 induce altered glycosylation compared to that indicated by TNF. The fact that tunicamycin pretreatment abolished $50 \%$ of the cell adhesion induced by TSFZR75.30 indicates that $\mathrm{N}$-glycosylated proteins such as VCAM-1 play an important rol in cell adhesion, other cell adhesion molecules such as E-selectin and ICAM-1 are likely involved in this process.

We assigned VCAM-1b to the spot with a $\mathrm{Mr} \sim 80 \mathrm{kDa} / \mathrm{pI}$ 4.6, the spot with $\mathrm{Mr} \sim 83 \mathrm{kDa} / \mathrm{pI}$ 5.1-5.2 we labeled as isoform " $\mathrm{c}$ ", which could correspond to the core protein of isoform "b", with different pI resulting from differential states of sialo-glycosylation at any of the five remaining $\mathrm{N}$ glycosylation sites. Alternatively, isoform "c" could also result from the loss of exons 2 or 8 , leading to a protein with a similar Mr as "b", but with an increase in the density of charge due to the preservation of all the reported glycosylations sites (Figure 2A).

The appearance of isoform "d", which was overexpressed in cells treated with TSFZR75.30, could be of potential clinical use as a biological marker for indicating the abnormal activation of endothelial cells by tumoral factors. Isoform " $\mathrm{d}$ " had the lowest molecular weight, which was suggestive of a smaller protein generated by alternative splicing or proteolytic processing. Interestingly when we interfered the process of $\mathrm{N}$-glycosylation, isoform " $\mathrm{d}$ " disappeared, and a new isoform "e" (Mr $77 \mathrm{kDa} / \mathrm{pI}$ 6.0) appeared. The fact that these two isoforms ("d" and "e") have the same apparent $\mathrm{Mr}$ suggests that they both correspond to the same core protein. It is likely, that the isoform " $\mathrm{x}$ ", identified in the Figure 2-B, corresponds to isoform e, since both were visible only in the presence of tunicamycin. According to the reported exon structure of VCAM-1, we evaluated the possibilities for the expected proteins when exons 2 (92 amino acids), 3 (107 amino acids), or 8 ( 89 amino acids) were eliminated. The predicted proteins had the following $\mathrm{Mr} / \mathrm{pI}$ values: 68928 $\mathrm{kDa} / 5.13,66997 \mathrm{kDa} / 5.14$, and $69376 \mathrm{kDa} / 5.01$, indicating that none of them could produce the observed " $\mathrm{e}$ " isoform, which had a $\mathrm{Mr} / \mathrm{pI}$ value of $\sim 77 \mathrm{kDa} / 6.0$. This analysis further supports the idea that isoform " $\mathrm{e}$ ", is encoded by all nine exons but lacks all N-glycosylation modifications. In addition, although we cannot discard other types of posttranslational modifications such as phosphorylation that could also explain the differences in pI of the different isoforms, these modifications have not been previously described for VCAM-1. Expression of VCAM-1 isoforms in tumors has not been well studied. In the past half-century, numerous studies have dealt with the effects of TSF's on endothelial cells. These studies have demonstrated that malignant cells produce a host of factors, most notably VEGF, that favor growth and vascular permeability, facilitating the spread of tumors [43-45]. In addition to cytokines and chemokines, our study also detected significant amounts of VEGF secreted by the breast cancer cell line ZR75.30. The complex mixture of soluble factors secreted by these cells reflects the multifactorial nature of signals emitted by tumor cells that can influence endothelial behavior [46]. The specific combination of cytokines, chemokines and growth factors, observed in the TSF's could serve as a signature to distinguish between tumor cells with different metastatic or invasive potentials in breast cancer.

\section{Conclusion}

Although it has been known for some time that altered glycosylation patterns of cell surface proteins, in particular increased sialylation, are associated with cancer cell adhesion, mobility, and invasion, only recently the functional significance of these changes has begun to be understood. This study documents variants of the $\mathrm{N}$-glycosylation state of VCAM-1 that can be induced in normal endothelial cells exposed to tumoral soluble factors derived from human breast cancer cells that could contribute to cell-cell adhesion and hence to malignancy [47-49].

\section{Methods \\ Cell cultures}

Human umbilical vein endothelial cells (HUVECs) were isolated and cultured $[50,51]$ by mixing cells from two or three human umbilical cords. The protocol to obtain the cells was approved by the ethics committee of the Gynecology and Obstetrics Hospital number 4 "Luis Castelazo Ayala", Mexican Institute of Social Security (IMSS), follow the principles of the Helsinki Declaration for human experimental research. Informed consent was also 
obtained. The culture medium was M-199 (Gibco BRL, Grand Island, NY), supplemented with $10 \%$ fetal bovine serum (In vitro, D.F. Mexico), 1\% glutamine (SIGMA, St Louis, MO), $20 \mu \mathrm{g} / \mathrm{ml}$ endothelial mitogen (Biomedical technologies, Stoughton, Ma), $100 \mu \mathrm{g} / \mathrm{ml}$ heparin (SIGMA, St Louis, Mo), and $100 \mathrm{U} / \mathrm{ml}$ penicillin/streptomycin (Gibco BRL, Grand Island, NY). Cells were grown on plastic tissue culture plates (Costar, Cambridge, MA) under an atmosphere of $95 \%$ humidity and $5 \% \mathrm{CO}_{2}$ at $37^{\circ} \mathrm{C}$. The cell culture reached confluence approximately 1 week after plating and presented a characteristic cobblestone appearance; cell cultures were used for all the reported experiments within their first passage. The myeloma cell line (U937) and breast cancer cell lines (ZR 75.30 and MCF-7) were obtained from ATCC, cultured in RPMI media supplemented with 10\% FBS, and grown under endotoxin-free conditions.

\section{Production of tumoral soluble factors}

Breast cancer cell lines were cultured until they reached $100 \%$ confluence. The cell layer was first washed 10 times with phosphate-buffered saline (PBS) and DMEM (1:1 v/ $\mathrm{v})$ in order to remove serum components. Then, the flasks were incubated with $20 \mathrm{ml}$ of serum free RPMI. After $48 \mathrm{~h}$, the culture medium (containing the soluble products derived from the breast cancer cell lines) was collected and lyophilized following centrifugation. The resulting powder was dissolved in $1 / 10$ of the original volume and dialyzed using a PM-10 ultra-filtration membrane (Millipore, Bedford, MA). The protein concentration was determined using the commercial Bradford reagent assay (BioRad, Hercules, CA). The resulting concentrated preparation containing the tumoral soluble factors from the breast cancer cell line ZR75.30 (TSFZR75.30) or the breast cancer cell line MCF-7 (TSFMCF-7), was kept at $4{ }^{\circ} \mathrm{C}$ until further use.

\section{Adhesion assay}

A suspension of $\mathrm{U} 937$ cells $\left(1 \times 10^{6}\right.$ cells $\left./ \mathrm{ml}\right)$ was radio labeled with thymidine $\left({ }^{3} \mathrm{H}\right)(1 \mu \mathrm{Ci} / \mathrm{ml})(\mathrm{NEN}$, Boston, MA) for $48 \mathrm{~h}$. Aliquots of the labeled cell suspension (250 $\times 10^{3}$ cells $/ 250 \mu \mathrm{l}$ ) were added to previously prepared wells containing HUVECs that had been grown and stimulated for $3 \mathrm{~h}$. The assay was performed in 48 well plates. After an additional $3 \mathrm{~h}$ of co-incubation, all the nonadherent 4937 cells were removed by aspiration, followed by two washes with PBS. The adherent cells were then immediately lysed with $500 \mu \mathrm{l}$ of $0.2 \mathrm{M} \mathrm{NaOH}$ and the radioactivity was measured in a scintillation counter (Beckman LS6000SC, St Louis, MO) [30].

\section{Tunicamycin treatment}

The tunicamycin concentration used was based on its Nglycan inhibitory effects on human cell cultures. HUVECs monolayers in Petri dishes were incubated with $1 \mu \mathrm{g} / \mathrm{ml}$ tunicamycin (SIGMA, St Louis, MO) for $3 \mathrm{~h}$ followed by TNF or TSFZR75.30 treatment. The cells were harvested 6 h later [52].

\section{Western blots}

Total protein concentration was determined using the commercial Bradford reagent assay (Bio-Rad, Hercules, CA). $20 \mu \mathrm{g}$ of total protein was used for the detection of VCAM-1. Samples were first boiled in sample buffer $(125$ $\mathrm{mM}$ Tris-HCl pH $6.8,1 \% \mathrm{v} / \mathrm{w}$ SDS, $10 \% \mathrm{v} / \mathrm{v}$ glycerol, $0.1 \%$ bromophenol blue, $2 \% \mathrm{v} / \mathrm{v}$ 2beta-mercaptoethanol) for 5 min and separated by $10 \%$ SDS-PAGE. Then, the gels were transferred to PVDF membranes (Bio-Rad, Hercules, CA) using a Trans-Blot Cell system (Bio-Rad, Hercules, CA) in transfer buffer (25 mM Tris, $190 \mathrm{mM}$ glycine, 10\% methanol) at $40 \mathrm{~V}$ overnight [53]. The following day, the membranes were probed for $1 \mathrm{~h}$ with mouse anti-human VCAM-1 (CD106) antibody (sc 13160 Sta. Cruz, Sta. Cruz, CA) diluted 1:500 in TBS buffer $(150 \mathrm{mM} \mathrm{NaCl}, 20$ $\mathrm{mM}$ Tris, $0.1 \%$ Tween, $1 \%$ BSA, pH 7.5). After washing, the membranes were incubated for $1 \mathrm{~h}$ with horseradish peroxidase linked to antimouse immunoglobulin (Pierce Rockford, IL). The signals were detected by enhanced chemiluminescence using the supersignal system (Pierce Rockford, IL) and quantified by densitometry. As a control, actin was simultaneously detected, using a mouse anti-human actin antibody. The antibody was diluted 1:1000 and developed using the same secondary antibody and chemiluminescence system previously described [54].

\section{Two-dimensional gel electrophoresis}

Confluent cells were either left untreated or treated for $6 \mathrm{~h}$ with TNF or TSFZR75.30. Cells were rinsed twice with PBS containing $\mathrm{Ca}^{++}$and $\mathrm{Mg}^{++}$, and harvested in lysis buffer containing $7 \mathrm{M}$ urea, $2 \mathrm{M}$ thiourea (SIGMA, St Louis, $\mathrm{MO}$ ), and $4 \% \mathrm{w} / \mathrm{v}$ CHAPS (Bio-Rad, Hercules, CA). Samples were centrifuged at $18000 \mathrm{~g}$ for $5 \mathrm{~min}$, the supernatants were recovered, and the pellets were discarded. The supernatants were then transferred to a new eppendorf tube, and the salts were removed from the samples using a 2-D Clean-up Kit (Amersham Biosciences, San Francisco, CA). $50 \mu \mathrm{g}$ of total protein was mixed with DeStreak rehydration buffer and 0.5\% IPG buffer, pH 3-10 (Amersham Biosciences Uppsala, Sweden) and applied to $7 \mathrm{~cm}$ IPG strips, pH 3-10 (Amersham Biosciences, San Francisco, CA), which were allowed to rehydrate for $15 \mathrm{~h}$ at room temperature. Separation on the first dimension was carried out using an IPGphor II isoelectric focusing system (Amersham Biosciences, Uppsala Sweden), as described by Görg in $1988[17,55]$. After the first dimension, the strips were balanced in two steps: (i) $15 \mathrm{~min}$ in a solution containing $6 \mathrm{M}$ urea, $50 \mathrm{mM}$ Tris (pH 8.8), 30\% glycerol, $2 \%$ SDS, and $70 \mathrm{mM}$ DTT, and (ii) $15 \mathrm{~min}$ in a similar solution contain $140 \mathrm{mM}$ iodoacetamide. After mounting the strips on $10 \%$ acrylamide gels, vertical electrophoresis 
was carried out using the Miniprotean III Bio-Rad system (Bio-Rad Hercules, CA). Proteins in the gels were visualized with the Deep-Purple stain solution (Amersham Biosciences, Bucks, UK) [1].

\section{Deep Purple gels stain}

Gels were stained according to instructions of the supplier http://www.amershambiosciences.com/. Briefly, the gels were first washed with distilled $\mathrm{H}_{2} \mathrm{O}$ for $30 \mathrm{~min}$, and then fixed in a solution of $7.5 \%$ acetic acid and $10 \%$ ethanol overnight. The next day, gels were stained with $5 \mathrm{ml}$ of deep purple diluted in $200 \mathrm{mM} \mathrm{Na}_{2} \mathrm{CO}_{3}$ for $30 \mathrm{~min}$ and then rinsed twice, 20 min each, with $50 \mathrm{ml}$ distilled $\mathrm{H}_{2} \mathrm{O}$ containing 7.5\% acetic acid. After that, gels were briefly washed in new last solution and imaged immediately in a Typhoon 9410 high performance analyzer ${ }^{\mathrm{TM}}$ using the 532 nm excitation laser. Protein spots were detected and quantified as fluorescent volumes; such a volume is the sum of the intensity of all pixels within the defined spot area. The gels with the highest number of spots were selected as reference gels and a combined warping with matching algorithm was used to create an average gel [56,57].

\section{D Western blots}

$50 \mu \mathrm{g}$ of total protein was used for the detection of VCAM$1 /$ actin for each of the treatments. The samples were separated in first and second dimension following the previously described protocols and transferred to an Immunoblot PVDF membrane (Bio-Rad, Hercules, CA). Membranes were blocked with $0.5 \%$ milk for $1 \mathrm{~h}$ and probed with mouse antihuman CD106 (VCAM-1) antibody (sc 13160 Sta. Cruz, Sta. Cruz, CA) diluted 1:500 in TBS with $3 \%$ BSA overnight at $4{ }^{\circ} \mathrm{C}$, following previously described western blots protocols.

\section{Electrophoretic mobility shift assay (EMSA)}

Nuclear protein extracts were obtained after treatments, in which the cells were washed, scraped, and pelleted at $4{ }^{\circ} \mathrm{C}$ and then frozen in ethanol-dry ice for $1 \mathrm{~min}$. The cells were immediately resuspended in $100 \mu \mathrm{l}$ of buffer A (10 mM HEPES, $10 \mathrm{mM} \mathrm{KCl}, 1.5 \mathrm{mM} \mathrm{MgCl} 2,1 \mathrm{mM}$ DTT, pH 7.9) and incubated for $10 \mathrm{~min}$ at $4^{\circ} \mathrm{C}$. Nuclei were microcentrifuged, resuspended in $30 \mu \mathrm{l}$ of buffer B $(20 \mathrm{mM}$ HEPES, $400 \mathrm{mM} \mathrm{NaCl}, 1.5 \mathrm{mM} \mathrm{MgCl} 2,0.2 \mathrm{mM}$ EDTA, 25\% glycerol, $1 \mathrm{mM}$ DTT, $0.5 \mathrm{mM}$ PMSF pH 7.9), and incubated on ice for $30 \mathrm{~min}$. Following another $20 \mathrm{~min}$ microcentrifuge step, the supernatant (nuclear protein extract) was diluted with $30 \mu \mathrm{l}$ of HDKE buffer $(20 \mathrm{mM}$ HEPES, $50 \mathrm{mM} \mathrm{KCl,} \mathrm{25 \%} \mathrm{glycerol,} 0.2 \mathrm{mM}$ EDTA, $1 \mathrm{mM}$ DTT, $0.5 \mathrm{mM}$ PMSF, pH 7.9). $10 \mu \mathrm{g}$ of the nuclear protein extracts were incubated with $\gamma$-ATP (32P) labeled oligonucleotide containing the decameric $\kappa \mathrm{B}$ site (5'AGTTGAGGGGACTTTCCCAGGC 3') (Santa Cruz, Sta. Cruz, CA). The binding reactions were carried out by incubating on ice for $40 \mathrm{~min}$ in reaction buffer (20 mM HEPES, $50 \mathrm{mM}$
KCl, 20\% glycerol, $0.2 \mathrm{mM}$ EDTA, $0.5 \mathrm{mM}$ PMSF, $1 \mathrm{mM}$ DTT, $1 \mu \mathrm{g} / \mu \mathrm{l} \mathrm{BSA}, 1 \mu \mathrm{g} / \mu \mathrm{l}$ poly-dI-dC) (Amersham Biosciences, Uppsala Sweden). The reaction mixture was loaded onto a $7.5 \%$ non-denaturing polyacrylamide gel, and was resolved at $120 \mathrm{~V}$ for $4 \mathrm{~h}$. The gel was dried and the DNA protein complexes were visualized by exposing the gel to a storage phosphor screen, imaged on a Storm Phosphorimager (Molecular Dynamics, San Francisco, $\mathrm{CA}$ ), and analyzed with the ImageQuant software (Molecular Dynamics, San Francisco, CA) [58].

\section{Bio-Plex assay}

The Bio-Plex suspension array system (Bio-Rad, Hercules, CA) is a microsphere-based immunoassay, which utilizes Luminex ${ }^{\mathrm{TM}}$ beads coupled to specific antibodies, as an analyte capture platform [59]. In total, $50 \mu \mathrm{l}$ of tumoral soluble factors secreted by the breast cancer cell line ZR75.30, was used for detecting the contents of secreted factors. The samples were added in duplicate to 96-well plates containing polystyrene beads from the 27-plex assay kit, and the beads were filter-washed twice with Bio-Plex wash buffer using a vacuum manifold (Millipore, Bedford, MA). Human cytokine standards were prepared in a range of concentrations from 32,000-0.2 $\mathrm{pg} / \mathrm{ml}$, added to the antibody-conjugated beads, and incubated in the dark on a platform shaker for $30 \mathrm{~min}$. Following incubation, the samples and standards were removed by vacuum, and the beads were filter-washed three times with Bio-Plex wash buffer. Afterwards, a 1:50 dilution of biotinylated detection antibody was added to the beads, followed by incubation in the dark on a platform shaker for $30 \mathrm{~min}$. The beads were washed three times and reacted with a 1:100 dilution of streptavidin-phycoerythrin (PE) for $10 \mathrm{~min}$. The beads were washed three times as described above, resuspended in Bio-Plex assay buffer, and analyzed on a Bio-Plex plate reader $[59,60]$.

\section{Bioinformatic tools}

Sequences of VCAM-1 were taken from the National Center for Biotechnology Information (NCBI) with the identification numbers: NP_001069 (VCAM-1a) and NP_542413 (VCAM-1b). Determinations of Mr/pI during the analysis of the VCAM-1 isoforms were done based on the same sequences using the Expert Protein Analysis System (ExPASy) proteomics server of the Swiss Institute of Bioinformatics (SIB).

\section{Statistical analysis}

All data sets were analyzed using two-tails Student's $t$ test.

\section{Abbreviations}

(HUVECs): Human umbilical vein endothelial cells; (TSF's): Tumoral soluble factors; (TNF): Tumoral necrosis factor; (VCAM-1): Vascular cellular adhesion molecule 1; 
(2D PAGE): Two-dimensional polyacrylamide gel electrophoresis; (Mr): Relative mass; ( $\mathrm{pI}$ ): Isoelectric point.

\section{Authors' contributions}

$D M S$ : carried out all the experiments, their analysis and wrote the manuscript. JLV: designed, carried out experiments and provided scientific advice to the manuscript. SF: isolated and established HUVECs cultures. IM: analyzed 2DE patterns with the software Image Master 2D Platinum. LM: performed the EMSA assays. AEN and FVO: provided and performed the Bio-Plex assays for the TSF's. $A Z D$ : designed and directed the phases of the research, analyzed the data, and critically reviewed and wrote the manuscript. All authors read and approved the final manuscript.

\section{Acknowledgements}

We are especially grateful to Dr. Guillermo Mendoza, for his supervision throughout the research and his critical review of all the experiments. We also thank Dr. Rocio Alcantara for her technical assistance with the analysis of densitometric values in western blots and, Dr. Manuel Hernández from CINVESTAV-IPN, Mexico for the actin mouse antibody he kindly donated. Finally, thanks to the Biological Sciences PhD Program, UNAM, for the administrative assistance and support. During the development of this project, DMS was a recipient of fellowships from CONACyT and UNAMDGEP. The project was supported also with the grant $45519 \mathrm{M}$ from CONACyT.

\section{References}

I. Bruneel A, Labas V, Mailloux A, Sharma S, Royer N, Vinh J, Pernet P, Vaubourdolle M, Baudin B: Proteomics of human umbilical vein endothelial cells applied to etoposide-induced apoptosis. Proteomics 2005, 5( I 5):3876-3884.

2. Zetter BR: Adhesion molecules in tumor metastasis. Semin Cancer Biol 1993, 4(4):219-229.

3. Ajani J, Allgood V: Molecular mechanisms in cancer: what should clinicians know? Semin Oncol 2005, 32(6 Suppl 8):2-4

4. Varki A: Biological roles of oligosaccharides: all of the theories are correct. Glycobiology 1993, 3(2):97-130.

5. Breen KC, Coughlan CM, Hayes FD: The role of glycoproteins in neural development function, and disease. Mol Neurobiol 1998, I 6(2): 163-220.

6. Vaughn DE, Bjorkman PJ: The (Greek) key to structures of neural adhesion molecules. Neuron 1996, I6(2):26I-273.

7. Sgroi D, Varki A, Braesch-Andersen S, Stamenkovic I: CD22, a B cell-specific immunoglobulin superfamily member, is a sialic acid-binding lectin. J Biol Chem 1993, 268(1 0):701 I-70I8.

8. Koukoulis GK, Patriarca C, Gould VE: Adhesion molecules and tumor metastasis. Hum Pathol 1998, 29(9):889-892.

9. Carson-Walter EB, Watkins DN, Nanda A, Vogelstein B, Kinzler KW, St Croix B: Cell surface tumor endothelial markers are conserved in mice and humans. Cancer Res 200 I, 6 I ( I 8):6649-6655.

10. Byrne GJ, Ghellal A, Iddon J, Blann AD, Venizelos V, Kumar S, Howell $A$, Bundred NJ: Serum soluble vascular cell adhesion moleculeI: role as a surrogate marker of angiogenesis. J Natl Cancer Inst 2000, 92(16): | 329-1336.

II. Madhavan M, Srinivas P, Abraham E, Ahmed I, Vijayalekshmi NR, Balaram P: Down regulation of endothelial adhesion molecules in node positive breast cancer: possible failure of host defence mechanism. Pathol Oncol Res 2002, 8(2): I 25- 128.

12. Holmes-McNary M: Nuclear factor kappa B signaling in catabolic disorders. Curr Opin Clin Nutr Metab Care 2002, 5(3):255-263.

13. Koch AE, Halloran MM, Haskell CJ, Shah MR, Polverini PJ: Angiogenesis mediated by soluble forms of E-selectin and vascular cell adhesion molecule-I. Nature 1995, 376(6540):517-5I9.
14. Pigott R, Dillon LP, Hemingway IH, Gearing AJ: Soluble forms of Eselectin, ICAM-I and VCAM-I are present in the supernatants of cytokine activated cultured endothelial cells. Biochem Biophys Res Commun 1992, I 87(2):584-589.

15. Rice GE, Bevilacqua MP: An inducible endothelial cell surface glycoprotein mediates melanoma adhesion. Science 1989, 246(4935): I 303-I 306.

16. Kamada H, Tsutsumi Y, Kihira T, Tsunoda S, Yamamoto Y, Mayumi T: In vitro remodeling of tumor vascular endothelial cells using conditioned medium from various tumor cells and their sensitivity to TNF-alpha. Biochem Biophys Res Commun 2000, 268(3):809-8I3.

17. Oh P, Li Y, Yu J, Durr E, Krasinska KM, Carver LA, Testa JE, Schnitzer JE: Subtractive proteomic mapping of the endothelial surface in lung and solid tumours for tissue-specific therapy. Nature 2004, 429(6992):629-635.

18. Utoguchi N, Mizuguchi H, Dantakean A, Makimoto H, Wakai Y, Tsutsumi $\mathrm{Y}$, Nakagawa S, Mayumi T: Effect of tumour cell-conditioned medium on endothelial macromolecular permeability and its correlation with collagen. $\mathrm{Br} J$ Cancer 1996, 73(I):24-28.

19. Estrada-Bernal A, Mendoza-Milla C, Ventura-Gallegos JL, LopezBojorquez LN, Miranda-Peralta E, Arechavaleta-Velasco F, VadilloOrtega F, Sanchez-Sanchez L, Zentella-Dehesa A: NF-kappaB dependent activation of human endothelial cells treated with soluble products derived from human lymphomas. Cancer Lett 2003, I 9 I(2):239-248.

20. Simiantonaki N, Jayasinghe C, Kirkpatrick CJ: Effect of pro-inflammatory stimuli on tumor cell-mediated induction of endothelial cell adhesion molecules in vitro. Exp Mol Pathol 2002, 73(I):46-53.

21. van Rossen ME, Hofland LJ, Tol MP van den, van Koetsveld PM, Jeekel J, Marquet RL, van Eijck CH: Effect of inflammatory cytokines and growth factors on tumour cell adhesion to the peritoneum. J Pathol 200I, I 93(4):530-537.

22. Kaji M, Ishikura $H$, Kishimoto $T$, Omi M, Ishizu A, Kimura C, Takahashi $T$, Kato $H$, Yoshiki T: E-selectin expression induced by pancreas-carcinoma-derived interleukin-I alpha results in enhanced adhesion of pancreas-carcinoma cells to endothelial cells. Int J Cancer 1995, 60(5):712-7I7.

23. Nizamutdinova IT, Lee GW, Lee JS, Cho MK, Son KH, Jeon SJ, Kang SS, Kim YS, Lee JH, Seo HG, et al:: Tanshinone I suppresses growth and invasion of human breast cancer cells, MDA-MB$23 \mathrm{I}$, through regulation of adhesion molecules. Carcinogenesis 2008.

24. McArthur HL, Dickler MN: Biomarkers in breast cancer. Cancer Biol Ther 2008, 7(I):21-22.

25. Gosk S, Moos T, Gottstein C, Bendas G: VCAM-I directed immunoliposomes selectively target tumor vasculature in vivo. Biochim Biophys Acta 2008, I 778(4):854-863.

26. Liotta LA, Kohn EC: The microenvironment of the tumourhost interface. Nature 200I, 4 I I (6835):375-379.

27. Quaranta V, Giannelli G: Cancer invasion: watch your neighbourhood! Tumori 2003, 89(4):343-348.

28. Castilla MA, Neria F, Renedo G, Pereira DS, Gonzalez-Pacheco FR, limenez S, Tramon P, Deudero J], Arroyo MV, Yague S, et al.: Tumorinduced endothelial cell activation: role of vascular endothelial growth factor. Am J Physiol Cell Physiol 2004, 286(5): CII70-II76.

29. Bogenrieder T, Herlyn M: Axis of evil: molecular mechanisms of cancer metastasis. Oncogene 2003, 22(42):6524-6536.

30. Lopez-Bojorquez LN, Arechavaleta-Velasco F, Vadillo-Ortega F, Montes-Sanchez D, Ventura-Gallegos JL, Zentella-Dehesa A: NF-kappaB translocation and endothelial cell activation is potentiated by macrophage-released signals co-secreted with TNF-alpha and IL-I beta. Inflamm Res 2004, 53( I 0):567-575.

31. Galbraith SM, Chaplin DJ, Lee F, Stratford MR, Locke RJ, Vojnovic B, Tozer GM: Effects of combretastatin A4 phosphate on endothelial cell morphology in vitro and relationship to tumour vascular targeting activity in vivo. Anticancer Res 200I, 2 I ( A):93-102.

32. Girdhar G, Chen Y, Shao JY: Double-tether extraction from human umbilical vein and dermal microvascular endothelial cells. Biophys J 2007, 92(3): I035-1045. 
33. Park HJ, Zhang Y, Georgescu SP, Johnson KL, Kong D, Galper JB: Human umbilical vein endothelial cells and human dermal microvascular endothelial cells offer new insights into the relationship between lipid metabolism and angiogenesis. Stem Cell Rev 2006, 2(2):93-102.

34. Murakami T, Mataki C, Nagao C, Umetani M, Wada Y, Ishii M, Tsutsumi S, Kohro T, Saiura A, Aburatani H, et al:: The gene expression profile of human umbilical vein endothelial cells stimulated by tumor necrosis factor alpha using DNA microarray analysis. J Atheroscler Thromb 2000, 7(I):39-44.

35. Rogers JA, Fuseler JW: Regulation of NF-kappaB activation and nuclear translocation by exogenous nitric oxide (NO) donors in TNF-alpha activated vascular endothelial cells. Nitric Oxide 2007, I 6(3):379-391.

36. Lopez-Bojorquez LN: [Regulation of NF-kappaB transcription factor. A molecular mediator in inflammatory process]. Rev Invest Clin 2004, 56(I):83-92.

37. Ji JY, Jing H, Diamond SL: Hemodynamic regulation of inflammation at the endothelial-neutrophil interface. Ann Biomed Eng 2008, 36(4):586-595.

38. Kobayashi H, Boelte KC, Lin PC: Endothelial cell adhesion molecules and cancer progression. Curr Med Chem 2007 I 4(4):377-386.

39. Mantovani A, Sozzani S, Vecchi A, Introna M, Allavena P: Cytokine activation of endothelial cells: new molecules for an old paradigm. Thromb Haemost 1997, 78(I):406-4|4.

40. Celis JE, Gromov P: High-resolution two-dimensional gel electrophoresis and protein identification using western blotting and ECL detection. Exs 2000, 88:55-67.

4I. Gromov PS, Ostergaard M, Gromova I, Celis JE: Human proteomic databases: a powerful resource for functional genomics in health and disease. Prog Biophys Mol Biol 2002, 80( I-2):3-22.

42. Matthies H Jr, Kretlow J, Matthies H, Smalla KH, Staak S, Krug M: Glycosylation of proteins during a critical time window is necessary for the maintenance of long-term potentiation in the hippocampal CAI region. Neuroscience 1999, 9 I(I):I75-I83.

43. Folkman J, Merler E, Abernathy C, Williams G: Isolation of a tumor factor responsible for angiogenesis. J Exp Med 197I, I33(2):275-288.

44. Folkman J: Endothelial cells and angiogenic growth factors in cancer growth and metastasis. Introduction. Cancer Metastasis $\operatorname{Rev} 1990,9(3):|7|-174$

45. Ferrara $\mathrm{N}$ : Vascular endothelial growth factor and the regulation of angiogenesis. Recent Prog Horm Res 2000, 55: I5-35. discussion 35-16

46. Umetani M, Mataki C, Minegishi N, Yamamoto M, Hamakubo T, Kodama T: Function of GATA transcription factors in induction of endothelial vascular cell adhesion molecule-I by tumor necrosis factor-alpha. Arterioscler Thromb Vasc Biol 200I, 2 I(6): $917-922$.

47. Campbell BJ, Yu LG, Rhodes JM: Altered glycosylation in inflammatory bowel disease: a possible role in cancer development. Glycoconj ] 200 I, I 8( I I- I 2):85 I-858.

48. Suzuki $O$, Nozawa $Y, A$ be $M$ : The regulatory roles of cell surface sialylation and $\mathbf{N}$-glycans in human $\mathbf{B}$ cell lymphoma cell adhesion to galectin-I. Int I Oncol 2006, 28(I): I55-I60.

49. Kyselova Z, Mechref Y, Kang P, Goetz JA, Dobrolecki LE, Sledge GW, Schnaper L, Hickey RJ, Malkas LH, Novotny MV: Breast Cancer Diagnosis and Prognosis through Quantitative Measurements of Serum Glycan Profiles. Clin Chem 2008, 54(7): II66-1 I75.

50. Jaffe EA, Nachman RL, Becker CG, Minick CR: Culture of human endothelial cells derived from umbilical veins. Identification by morphologic and immunologic criteria. J Clin Invest 1973, 52(I I):2745-2756.

5I. Horrevoets AJ, Fontijn RD, van Zonneveld AJ, de Vries CJ, ten Cate JW, Pannekoek $\mathrm{H}$ : Vascular endothelial genes that are responsive to tumor necrosis factor-alpha in vitro are expressed in atherosclerotic lesions, including inhibitor of apoptosis protein-I, stannin, and two novel genes. Blood 1999 , 93(10):3418-343I.

52. Alpaugh ML, Lee MC, Nguyen M, Deato M, Dishakjian L, Barsky SH: Myoepithelial-specific CD44 shedding contributes to the anti-invasive and antiangiogenic phenotype of myoepithelial cells. Exp Cell Res 2000, 26I(I): I50-158.
53. Laemmli UK: Cleavage of structural proteins during the assembly of the head of bacteriophage T4. Nature 1970, 227(5259):680-685.

54. Mendoza-Milla C, Machuca Rodriguez C, Cordova Alarcon E, Estrada Bernal A, Toledo-Cuevas EM, Martinez Martinez E, Zentella Dehesa A: NF-kappaB activation but not PI3K/Akt is required for dexamethasone dependent protection against TNF-alpha cytotoxicity in L929 cells. FEBS Lett 2005, 579( I 8):3947-3952.

55. Gorg A, Postel W, Gunther S, Weser J, Strahler JR, Hanash SM, Somerlot L, Kuick R: Approach to stationary two-dimensional pattern: influence of focusing time and immobiline/carrier ampholytes concentrations. Electrophoresis 1988, 9(I):37-46.

56. Chevalier F, Rofidal V, Vanova P, Bergoin A, Rossignol M: Proteomic capacity of recent fluorescent dyes for protein staining. Phytochemistry 2004, 65( I I): |499-|506.

57. Harris LR, Churchward MA, Butt RH, Coorssen JR: Assessing detection methods for gel-based proteomic analyses. I Proteome Res 2007, 6(4): |4|8-|425.

58. Machuca C, Mendoza-Milla C, Cordova E, Mejia S, Covarrubias L, Ventura J, Zentella A: Dexamethasone protection from TNFalpha-induced cell death in MCF-7 cells requires NF-kappaB and is independent from AKT. BMC Cell Biol 2006, 7:9.

59. de Jager W, te Velthuis H, Prakken BJ, Kuis W, Rijkers GT: Simultaneous detection of I 5 human cytokines in a single sample of stimulated peripheral blood mononuclear cells. Clin Diagn Lab Immunol 2003, I O(I): I33-I39.

60. Azizan A, Sweat J, Espino C, Gemmer J, Stark L, Kazanis D: Differential proinflammatory and angiogenesis-specific cytokine production in human pulmonary endothelial cells, HPMECSTI.6R infected with dengue-2 and dengue-3 virus. J Virol Methods 2006, I38(I-2):2II-2I7.

Publish with Bio Med Central and every scientist can read your work free of charge

"BioMed Central will be the most significant development for disseminating the results of biomedical research in our lifetime. "

Sir Paul Nurse, Cancer Research UK

Your research papers will be:

- available free of charge to the entire biomedical community

- peer reviewed and published immediately upon acceptance

- cited in PubMed and archived on PubMed Central

- yours - you keep the copyright 